\title{
Ensinando em uma Universidade Soviética
}

\section{Guido Beck}

Anteriormente no Instituto de Física Teórica da Universidade de Leipzig

Tradução: Juan A. Queijo

Recebido em 20/11/2017

Aceito em 21/11/2017
Para citar este artigo: MACHADO, Cristina de Amorim. A literatura como meio de avaliação da produção científica e o problema da autoria em ciência. Em Construção. ano 1, n. 1, 2017, pp. 5-24. DOI:10.12957/ emconstrucao.2017.28122
Durante os meus dois anos de estadia na União Soviética ${ }^{1}$, me interessei em organizar um curso universitário no meu campo de especialidade. Eu percebia que não poderia haver um progresso real no trabalho de pesquisa em física teórica até que um grupo de jovens estudantes bem treinados estivesse disponível. Em Odessa, tive o privilégio de colaborar com um cientista da Zurique [Marcel Schein], que ocupava a cátedra de Física Experimental. Ampliei o meu trabalho para a Universidade de Kiev. Procurei respeitar os critérios previamente aceitos pelas universidades alemãs, e elaborei um curso completo de física teórica que foi traduzido para o ucraniano. Uma vez que esse esforço foi apoiado pelo Comissariado Ucraniano de Educação Nacional, espero que o meu trabalho consiga manter-se útil para as universidades ucranianas. Não consegui, contudo, dar continuidade ao meu contrato em Odessa dadas as desagradáveis condições atuais, já que a posição de quase todo russo, que está em um posto de comando, é tão instável que ninguém ousa tomar alguma iniciativa ou aceitar responsabilidades. Nenhum trabalho construtivo pode, então, ser feito. Apesar disso, eu lamentei muito ter de deixar o pequeno grupo de jovens que tinha começado a se interessar por física.

No que diz respeito à Educação Nacional, o principal interesse da Russia Soviética é direcionado para o desenvolvimento do ensino básico e do ensino médio. Estes estão organizados em um sistema de dez anos (desde os oito até os dezoito anos de idade). Um grande número de belos prédios escolares está sendo construído. O salário dos professores de escola foi recentemente quase duplicado e, no momento, os professores são um dos grupos de empregados com melhor pagamento. Ainda há uma tremenda falta de professores de escola nos distritos do interior, mas, nas cidades,

1 O Professor Beck passou os anos académicos de 1935-36 e 1936-37 ensinando na Universidade de Odessa. 
desde que os novos salários entraram em vigor, há um excesso de oferta. O nível médio dos professores das escolas e universidades é muito baixo e pode ser comparado aos níveis da Europa no século passado [século XIX]. Fiz muitos comentários sobre o atual treinamento inadequado dos professores, mas não tive muito sucesso com isso. As autoridades administrativas estão sob muita pressão para dar conta da produção anual de professores requerida; nas universidades, existe ainda um defeituoso sistema de autoadministração pelos estudantes que muitas vezes interfere com as exigências do treinamento nas universidades. Cinco anos de treinamento são necessários para o ensino na universidade. Alguns progressos foram alcançados desde que se abandonou a "distinção de classe". Todo aquele que preenche os requerimentos para treinamento das escolas é admitido para fazer as provas prévias ao ingresso na universidade, onde um número limitado de estudantes é selecionado. Esse número é fixado anualmente de acordo com as necessidades planejadas. No momento, isto excede o número de candidatos bem preparados e muitos candidatos, que tem uma preparação precária, conseguem ingressar na universidade. É possível esperar uma melhora nos próximos anos quando crescer significativamente o número de pupilos com dez anos de treinamento escolar.

Os estudantes que ingressam na universidade dispõem de alojamento e bolsas de estudo. Contudo, eles são terrivelmente saturados com palestras, cento e cinquenta horas obrigatórias mensais de palestras, e com frequentes encontros de natureza político-administrativa. As palestras não são mantidas regularmente como deveria ser o caso. Permite-se a um grande número de organizações interferir nos programas de ensino. Deste modo, muito pouco espaço é reservado para o trabalho individual e para os interesses dos estudantes. Ninguém parece se importar com os estragos que resultam de um treinamento inadequado. Mesmo os professores contribuem para aumentar esse esgotamento dos estudantes, uma vez que os salários dependem do número de palestras dadas. Era dado como certo que avaliações deveriam ser realizadas frequentemente, mas, muitas vezes, é feita pressão contra estas pelos próprios estudantes e mesmo pelo corpo administrativo. Os professores acabam por ficar tão esgotados, como os próprios estudantes, devendo dar conta de um número incrível de exigências. Assim, muito pouco trabalho cientifico pode ser realizado. A administração tenta se impor através de "planos" definitivos ao invés de estimular o trabalho cientifico. Eu não acredito que se possa esperar algum resultado neste sentido. Infelizmente, esta situação levou a que muitos cientistas do país fugissem para outros institutos de pesquisa, o que torna ainda mais grave a situação das universidades. Assim, uma mudança radical tem que acontecer para que as universidades soviéticas sejam providas com um sistema de ensino satisfatório.

Para reorganizar as universidades e outras escolas superiores, um comitê central foi estabelecido em Moscou há algum tempo. Por enquanto, parece-me que é assunto muito complicado fornecer a centenas de escolas superiores programas de ensino detalhados e centralizados; só uma grande experiência pode trazer sucesso. As medidas apresentadas pelo novo comitê, ao menos naquilo que diz respeito à física, não conseguiram convencer-me de que uma base satisfatória para o ensino universitário poderá ser alcançada no futuro próximo. Apesar disso, há razões que me fazem crer no futuro das universidades soviéticas com todo o seu potencial de capacidades. Encontrei uma apreciação ampla e sincera pela ciência e pelo trabalho cientifico na União Soviética. E fiquei muito feliz de ver que, apesar de o nível geral ser muito baixo, há, entre os estudantes russos, um alto percentual de jovens com capacidade e ambição, os quais, uma vez apoiados por um sistema de ensino adequado, poderão em um período de tempo relativamente breve - digamos dez anos -, mudar radicalmente a triste situação atual e dar uma contribuição considerável para um aumento na média do nível educacional no pais. 


\section{Teaching in a Soviet University}

\section{Guido Beck}

Formerly of the Institut fur Theoretische Physik of the University of Leipzig

During my two years' stay in the Soviet Union ${ }^{2}$ I was primarily interested in organizing university teaching in my special branch. I felt that no real progress in research work in theoretical physics was possible until a certain number of well trained young people was available. In Odessa I had the privilege of collaborating with a scientist of Zurich who held the Chair of Experimental Physics. I also extended my work to the University of Kiev. I tried to follow the lines previously accepted in German universities and I elaborated a complete course of theoretical physics which was translated into the Ukrainian language. Since my efforts were supported by the Ukrainian Commissariat of National Education, I hope that my work will remain of some use to the Ukrainian universities. I did not find it possible, however, to extend my contract in Odessa under the present unpleasant conditions, when the position of almost every Russian in any commanding post is so unsettled that nobody dares to take any initiative or responsibility and no constructive work can be done. However, I felt very sorry to leave the small group of young people who had become very much interested in physics. As far as national education is concerned, the main attention in Soviet Russia is paid to the development of elementary and middle schools. These are organized on a ten-year training system (from eight to eighteen years of age) . A large number of quite attractive looking new school buildings is under construction. Recently the salaries of school teachers have been almost doubled and teachers are at present among the best paid groups of employees. There is still a tremendous lack of school teachers in the country districts though the cities, since the new salaries have been in force, are oversupplied. The average level of the teaching staff in schools and universities is very low and can be compared with the European level of a century ago. I objected very much to the present inadequate training of teachers, but I was not very successful in this respect. The administrative authorities are under pressure to furnish the required annual output of teachers and in the universities there still exists a very unsound system of self-administration by the students which often interferes with the requirements of university training. Five years of training is required for university teaching. Certain progress has been made since the abandonment of the "class distinction". Anyone fulfilling the requirements for school training is admitted to examinations to be passed before entering the university and a limited number of students is selected. This number is determined annually according to the anticipated need. At present this exceeds the number of well prepared candidates and many poorly prepared students enter the universities. An improvement may be expected in a few years when the number of competing pupils with ten years' school training will be greatly increased. Students entering the university are provided with rooms and with a fellowship. They are, however, terribly overburdened with lectures, one hundred fifty hours of compulsory lectures monthly,-and with very frequent meetings of a political and administrative character. Lectures are not held as regularly as they should be, a great number of organizations being allowed to interfere with the teaching program. Thus very little room is left for individual work and interests of the student, and nobody seems to realize the damage which results to an adequate training. The teaching staff, itself, is inclined to increase the students' burden since salaries depend on the number of lectures given. Frequent examinations are supposed to be held but strong pressure against these is often exerted by the students as well as by the administration. The teaching staff is overburdened as are the students, and has to meet an incredible number of requirements.. Very little scientific work can be expected at present. The administration attempts to enforce according to definite "plans" rather than to stimulate scientific work. I do not believe that any results can be expected in this way. Unfortunately, this situation has led to a flight of most of the country's scientists to a few privileged research institutes, still more aggravating the situation in the universities. Thus, radical changes would have to take place in order to provide Soviet universities with a satisfactory teaching system. In order to re-organize the universities and other higher schools, a central committee was set up in Moscow some time ago. It seems to me, however, that it is an extremely complicated

$2 *$ Professor Beck spent the academic years 1935-36 and 1936-37 teaching at the Univer-sity of Odessa. 
task to provide hundreds of higher schools with detailed, centralized teaching programs, and that only very long experience would bring success. The measures being projected at present by the new committee, at least as far as physics is concerned, did not convince me that a satisfactory basis for university teaching will be found in the very near future. Nevertheless, there are reasons which make me believe in the future of Soviet universities, with their vast potential capacity. I have found, indeed, a very common and sincere esteem for science and scientific work in the Soviet Union. And I have been very happy to see that, though the average level is very low, there is among Russian students a comparatively high percentage of very able and ambitious young people who, once they can be provided with an adequate system of education, could within a comparatively short time,-_say within ten years,-radically change the present unfortunate situation and could contribute considerably to a large scale rise of the average educational level of the country. 